boards at both national and institutional levels. The national board, known by its Hungarian acronym, FTT, is composed of 21 members: half nominated by the higher education sector, half coming from users such as employers and professional associations, and one government representative. The FTT is purely an advisory body to the Ministry of Education, but its powers are significant-ranging from the development of an overall strategic plan to the allocation of admission places in universities.

The rationale for including boards in the overall reform program was twofold. First, boards represented a structural solution to the reform objective of "responsiveness" to changing social and economic conditions. Boards composed of users of higher education's products could help clarify and promote needed changes. Second, from the universities' point of view, boards could serve a classic "buffering" function of protecting them from the vicissitudes of political forces.

Implementation of both reform elements illustrated here has been a struggle. Structurally, the Prussian model has difficulty accommodating the emergence of power in the middle-anything between the state and the professoriate. Additionally, each case illustrates the powerful legacies of the socialist system in shaping attitudes toward reform. One of the central dynamics of socialist systems has been the state bureaucracy's control over allocation and a resulting culture of subordination. Ministry officials would not allow the FTT to function as the principal advisory body for higher education on issues of integration or any other major policy arena. Another closely related characteristic of socialist societies is the absence of "civil society" or nongovernmental institutions occupying the intermediate space between government and individuals. Boards are a foray into this intermediate space and it has been a difficult pioneering venture in terms of legitimacy and power.

Clearly integration and other elements of reform have encountered the classic dynamics of interest group behavior found in all societies. Integration leaders come from regional universities eager to increase their influence and resources. Resistance comes from the larger and more powerful Budapest universities protecting their status. The legacies of socialism have further shaped and reinforced this dynamic through an established pattern of networks between ministry bureaucrats and institutional leaders created to cope with the constraints of a "shortage economy" characteristic of socialist countries.

After the euphoria of 1989, the realities of significant reform in higher education in Hungary have become apparent as some groups resist change and seek to protect perceived interests and beliefs. However, the legacies of socialist systems constitute deeply rooted ways of thinking and acting that lie not in the particular political system but in the social and economic structures upon which these societies were built. Many involved in higher education reform in Hungary have concluded that change will take a generation or two.
Brain Korea 21:

\section{A Development-Oriented National Policy in Korean Higher Education}

\section{Gilton Eun-Jun Lee}

Gilton Eun-Jun Lee is a doctoral candidate in the higher education administration program, Boston College. E-mail: <leeeh@bc.edu>.

$\mathrm{O}$ n June 15, 1999, about 1,000 professors demonstrated in the street in Pusan, the second-largest city in Korea. Their slogan was "Withdraw Brain Korea 21!" Three weeks later, about 900 professors gathered for another demonstration in the capital, Seoul. Their demand was the same, "Withdraw BK21!" In the history of Korean higher education, there has never been a national education policy against which university professors have publicly protested.

\section{The Brain Korea 21 Project}

In spring 1999, the Korean government established a new national education policy to prepare Korean higher educa- tion for the 21st century. The policy, "Brain Korea 21" (BK21), has several purposes: to develop world-class research universities, foster the creation of human resources through graduate schools, nurture quality regional universities, and reform higher education. To accomplish this, the government has decided to invest 1.4 trillion won (about U.S.\$1.2 billion) into higher education over seven years. Three-quarters of the budget will be invested in supporting graduate schools in certain fields in the natural and applied sciences, humanities, and social sciences. The goal is to develop selected graduate schools and universities into leading world-class research universities in the near future. The remaining institutions will become regional universities that will create the human resources required by local industrial societies.

The project operates on the principle of "selection and concentration." All universities applying to the project must establish research consortia of collaborative networks among competent university researchers. Each research consortium consists of one leading university and one or more participating universities. The government provides financial resources to selected consortia.

The most distinctive feature of BK21 is that graduate students in the selected graduate schools will be the direct 
beneficiaries of the project. Research funds will not go directly to professors in the form of grants. In large part the budget will be used to provide a supportive educational environment for graduate students in the form of stipends, financial support for overseas study, research infrastructure, and so on. That is the main reason why the project is called Brain Korea 21.

The government and the Ministry of Education predict that when the project is completed, the universities selected for support will have been transformed into worldclass research universities. They anticipate that 2,000 graduates with doctorates and 200 with professional degrees will be produced in selected research fields each year and that the amount of scientific research registered with the Social Science Citation Index will be dramatically increased.

\section{The Pros and Cons of BK21}

BK21 is an unprecedented policy in terms of its scale and planning-ambitious in its attempt to reform and develop Korean higher education. Proponents argue that past policies in higher education finance have focused on distributing of limited resources fairly among all colleges and departments. BK21 will change the focus to efficiency of investment rather than equality of opportunity in the distribution of research funds. Supporters of BK21 also maintain that various research consortia supported by the project will create the intellectual foundation for Korean higher education and society. Furthermore, shifting the focus of higher education from undergraduate to graduate education will mitigate the overheated competition for entering top-tier universities.

The opposition to BK21 is based on concerns among many faculty about the possible negative impacts of the project. First, the opponents argue that most professors in Korea, except some in top-tier universities, have always had trouble obtaining research funds. If the traditional top universities are selected and supported by BK21, the principle of "selection and concentration" will prevent most professors in nonselected colleges and universities from getting their research funded. Furthermore, BK21 may be detrimental to fair competition among universities, reinforcing the traditional pecking order, which has long been perceived as an obstacle in the development of Korean higher education.

Second, most academics suspect that the government is trying to reform Korean higher education through the enforcement of BK21. The Ministry of Education requires a prerequisite for participation in the project: every selected university must undertake educational reforms under the direction of the Ministry of Education-such as, reducing the number of undergraduate students, hiring professors who teach only at the graduate level, and improving university curricula. Considering that most Korean colleges and universities have lacked autonomy in many ways, the administrative devices of BK21 may further depress autonomy levels in Korean higher education.

Third, although the goal of BK21 was to strengthen research capacity in Korean higher education, critics argue that the project will seriously weaken research activities in the majority of colleges and universities because of insufficient numbers of graduate research assistants. Universities supported by BK21 will receive enough funds to support their graduate students and will thus have a great advantage in attracting well-qualified students to their programs. By contrast, most graduate schools in nonselected universities may loose students due to a relative lack of research facilities and financial support for graduate students. In fact, since the Ministry of Education announced the results of the selection process, many more undergraduate students have applied to graduate programs in the selected universities and academic fields supported by BK 21 .

\section{Considering that most Korean colleges and universities have lacked autonomy in many ways, the administrative de- vices of BK2 1 may further depress au- tonomy levels in Korean higher education.}

\section{Remaining Issues}

Over the objection of many academics, the Ministry of Education is proceeding with the project, with some minor modifications. Despite any problems inherent in BK21, certain universities and fields of study may receive a significant boost from the project. In economic terms, such as maximizing the benefits of limited resources, BK21 may be a rational policy that will yield visible achievements in the near future. However, the professors' protests and objections against BK21 imply a failure in the agenda-setting process. In fact, the Ministry of Education did not publicly consult with the higher education community and failed to hold any public hearings before the official announcement of the project. Moreover, other controversial issues-such as uneven development among academic fields and the overdependence on government funding - may also weaken the effort to promote academic autonomy in Korean higher education. The success or failure of Brain Korea 21 will show the effect on higher education of a development-oriented and government-controlled educational policy.

Author's Note: I would like to thank Dr. Sungho Lee (Yonsei University, Korea) for helpful comments on an earlier draft of this article. 